\title{
Re-thinking the dynamics of a pluralistic society in Acts 15:1-35 and contemporary Zimbabwean society: A Narratological Approach
}

\author{
Tobias Marevesa (PhD) \\ Philosophy and Religious Studies Department \\ Simon Muzenda School of Arts, Culture and Heritage Studies \\ Great Zimbabwe University, \\ tmarevesa@gzu.ac.zw \\ https://orcid.org/0000-0001-5479-6735 \\ Doi: https://doi.org/10.46222/pharosjot.102.027
}

\begin{abstract}
From time immemorial, ethnic diversity in society often resulted in conflict instead of cooperation. Religion played a pivotal role in uniting or dividing people. In the New Testament world, James Dunn (2006) describes the dynamics of a pluralistic society as that of unity in diversity. Furthermore, other prominent scholars in the New Testament studies such as Haenchen (1985:467) and Witherington (1998:439) aptly describe Acts 15:1-35 as a "turning point" and a "watershed", respectively, in relation to the dynamics of ethnic conflict resolution. The main thrust of this paper to interrogate a conflict-resolution in the pluralistic environment of Acts 15. This paper will be informed by insights and the lens of narrative method. The coming of this method into the New Testament studies was not well received by traditional scholars who viewed it as taking the Bible as fictional as work. Nevertheless, this paper maintains that the Council of Jerusalem in Acts 15 (50 CE) can be examined and analysed using narratological insights.
\end{abstract}

Keywords: Narrative-critical approach, Zimbabwe, pluralistic society, Book of Acts.

\section{Introduction}

Keegan (1995:92) defines the narrative-critical approach as "a highly developed methodology for studying biblical narratives from the perceptive of reader involvement." This methodology can also be understood as an approach to theory of literature in which narrative literature is analysed and examined (Van Aarde, 2009: 383). From these definitions, a narratological approach emphasises the importance of reader involvement in the examination of formal features of biblical narratives and the construction of meanings. This is because the Jerusalem Council of $50 \mathrm{CE}$, has the aspects that are considered when one is analysing any other story. Acts 15 will be examined as a story which took place in a pluralistic society where Judaisers, Jewish Christians and Gentile Christians were in conflict on the acceptability of Gentiles in the Christian community. The meaning of the Lucan story in Acts 15 will be analysed in terms of plot, characterisation and rhetoric points of view among other narrative aspects. Finally, the insights and principles from Acts 15 will be contextualised as a conflict resolution model for the challenging Zimbabwean political landscape.

\section{Plot}

According to Resseguie (2005:197) the word "plot" is difficult to define with precision. Nevertheless, it is important to at least attempt to understand what a plot is. It is generally understood as a structure of events that take place within a story (Du Toit, 2009:386; Resseguie 
2005:197; Marguerat \& Bourquin, 1999:40; Osborne, 1991:158). In other words, a plot includes ordering of events that build up to a climax as well as involving the reader in the story. With regards to the Council of Jerusalem in $50 \mathrm{CE}$, the story unfolds with dissension between Jewish and Hellenist Christians, which is sustained until the conflict is resolved by the release of the apostolic decree. A plot has a linear arrangement of actions with the beginning, middle and conclusion (Du Toit, 2009:386). A plot can be either macro (be seen as a whole book), or micro (as a single section within a book). For example, the book of Acts can function as macro, while the Jerusalem Council can be viewed at micro level. The plot in the Jerusalem Council will be treated as a micro level one because it functions as a section within the book of Acts.

\section{Plot in the Jerusalem Council of 50CE Narrative}

We identify two major forms of plots in the New Testament which are comedy and tragedy (Resseguie, 2005:205; Marguerat, 1999:48). The tragic plot starts with a conflict at the beginning of the story. The conflict develops until the situation goes out of hand resulting in a disaster (Brant, 2004:123). Whereas the comedy with a condition of stability, after a time of good fortune, is disturbed by misfortune or tragedy. Confusion or revolt drives the plot downward to ultimate catastrophe. At the bottom of the comedy the course of action is changed by a prosperity turn, freedom from God, the emerging of the character in the story from his or her awful situation, "or some other action or event that results from upward turn" (Resseguie, 2005:205). The comic plot is reminiscent of the plot in the Council of Jerusalem in Acts 15. Relating this comic plot to the Council of Jerusalem, when Barnabas and Paul were in Antioch in a Gentile community, they were excited by their mission work (Elmer, 2006:6). A number of Gentiles were giving their lives to God. The situation was in a condition of equilibrium, prosperity and happiness. This situation was disturbed by the coming in of "certain men who came down from Judea" (Acts 15:1). These men insisted that, "except you are circumcised by the Law of Moses, you cannot be saved" (Acts 15:1). These men were believed to be Judaisers.

The misunderstanding or rebellion drove the plot downward to dissention and conflict. This situation resulted in convening of the Council of Jerusalem Council. After the negotiations, mediations and debates, there were agreements and resolutions. At the bottom of the 'tragic plot the course of action was transformed by prosperity twists, and there was a divine intervention where characters in the tragic circumstances changed resulting in an upward twist. For the Council of Jerusalem Council, the presentations which were made by Peter and James led to the resolution of the conflict. That means the tragic situation in which Paul and Barnabas found themselves changed with an upward turn. Resseguie (2005:205) asserts that the reversal in

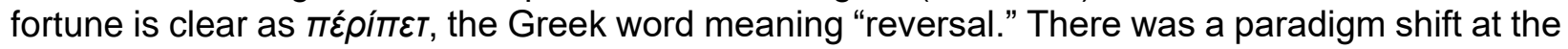
council because of the proclamation or judgement of James by declaring the apostolic decree which the Gentiles were supposed to follow.

The change of course of action signals what Marguerat and Bourguin (1999:51) and Du Toit (2009:386) call the denouement, a French word meaning "unravelling" or "solution of the plot." In other words, at the end of the story, precautions are taken to end the conflict. All the misunderstandings are solved and the agitation stops. Resseguie (2005:205) notes that often narrators will usually have sections where they round-off the story in trying to make particular stories complete wholes. In the Council of Jerusalem Council, the apostolic decree is made, which instructs gentiles to abstain from: (1) meat offered to idols (2) meat of strangled animals ( (3) sexual immorality (4) blood (Acts 15:29). All these prohibitions were crafted in order that both the Gentile and Jewish Christians could fellowship together. In this way, the apostolic decree also contributed to the development of the plot and eventually resolving the conflict. In addition, as a conflict-resolution measure, there were two men (Silas and Judas) who were chosen to go and 
support orally the written document (decree) to the intended audience. Parsons $(2005: 20)$ posits that the bearers of the letter were both in the decision and the resolution. The intended objective of the apostolic decree was fulfilled because the desired results were: "they rejoiced because of its encouragement" (Act 15:31). However, it does not necessarily mean that the ending of a story will dissolve the conflict, but some stories may be open-ended (Du Toit, 2009:387).

\section{Analysis of Acts 15: 1-35 from a narrative point of view}
(a) Is Acts 15:1-35 a narrative?

The story in the Jerusalem Council is structured with characters such as Peter, John, James, and others. The story starts from Antioch and moves to Jerusalem in a clear sequence of events developing a tragic plot with discussion, dialogue and finally resolution.

\section{(b) The situation of the narrator'}

In the narrative of the Jerusalem Council, there is third person narration where the narrator is outside the story-line. This type of a narrator calls characters by name and or by their designated titles. For instance, the narrator calls people by proper names like Peter, Paul or Barnabas or the Son of God.

\section{(c) The narrator's spatial situation}

In Acts 15:1-35, the narrator embraces a limited point of view technique; this is seen from the beginning of the story up to the end. From 15:1-11 (the conflict over circumcision), 15:12-21 (James' judgement), and 15:22-35 (the letter to the Gentile Churches), and the whole procedure to resolve conflict at the Council Jerusalem is evidence that the narrator adopted the limited point of view. Probably the narrator used this technique of limited point of view because he (narrator) anticipated the implied reader to associate with all characters who participated in the whole story of conflict-resolution (Du Toit, 2009:410). It can be pointed out that both the hard-liners and the readers who sympathised with them are often viewed in the book of Acts as people who exclude the Gentiles in every respect in their lives. The narrator did this by giving the Gentiles the burden of observing the Law of Moses which their ancestors had failed (15:10).

(d) The narrator's psychological situation

The narrator can describe the actions of characters either externally (omniscient) or internally (limited) (Du Toit, 2009:394). In the event that narration is done in third person, it implies that the narrator is external. With regards to the Council of Jerusalem Council, the limited point of view is apparent in the whole story with the exception of the verses 13 and 16 to 20 where there is an omniscient point of view.

\section{The narrated discourse}

\section{(i) Time}

Acts 15:1-35 consists of thirty-five verses. V. 1-11 is the question whether circumcision is necessary, v. 12-21 James' judgement, and lastly v. 22-35 where the letter is sent to Churches. At the Jerusalem Council, there were delegates from Antioch who came for the conference.

\section{(ii) Setting}

The commencement of the plot moves from Acts 15:1-35, where the problem of Gentile inclusion into the Christian community is attended to and resolved. This narrative is divided into four scenes 
which are: a conflict clarification (15:1-5); discussion in Jerusalem on the presentations of Peter, Barnabas and Paul (15:6-12) and James (15:13:-21); conflict resolution (15:22-29); the resolution disseminated to Antioch (15:30-35). The middle of the story stretches from v.6-29 where speeches were presented followed by discussions, negotiations and mediation which eventually led to the resolution of the conflict. The story ends with the report being distributed to Antioch v.30-35. The narrated time often changed with commented time, like in v.1-2 where there is antagonism against the Gentiles. The same applies to v.6-7 where Peter recounted his experience with Cornelius, and the speech of James (judgement) in v.13-18.

\section{(iii) Story Time and "plotted time"}

The "narrative" in Acts 15 comprises the following scenes:

- The conflict

- Speeches by Peter, James, Barnabas and Paul

- conflict resolution

- Distribution of the report (letter

The plotted time is different from the story time in that the story time focuses on the "reconstruction of the chronological story and the identification of all digressions on the narrative discourse" (Du Toit, 2009:402). While plotted time explores the narrator's theological or ideological viewpoint which defines the chronology and causality among a variety of incidents as well as the intention behind the deviations from a sequence of actions linear, and the likeness which is there between different story lines (Du Toit, 2009:402). In order to find out the ideological point of view which controls the chronology and causality of the above mentioned proceedings, it is imperative to consider their chronological sequence. From the first to the second episode, the transition is that the narrator emphasizes the acceptability of the inclusion of the Gentiles the community of Christians, though the Pharisees' Party were demanding Gentiles to observe the Mosaic Law.

The narrator's first port of call was to prepare his readers for a theological issue which was to be raised at the Jerusalem Council. The narrator implicitly acknowledges the previous incidents where he had initiated the inclusion of the Gentiles like the day of Pentecost (2:5-12), the story of the Ethiopian eunuch (8:26-40), and the story of Cornelius (10:1-11:18) which were very important to the Jerusalem Council. It is because of the experiences of Peter's missionary work which were instrumental for the approval of the mission to the Gentiles into the Christian community. During the process of disputes James based his judgement on what Peter had said in his presentation. Another ideological dimension which is evident in the Council of Jerusalem is seen in the two versions of compromise (Acts 15:20,29) where the decree was crafted as a code of conduct for the Gentiles. It is also important that Acts 15:1-35 is a story that binds together with other stories within Acts, for which the Jerusalem Council becomes the watershed of the book (Witherington, 1998:439; Haenchen, 1985:467). The implication is that, Acts 10:1-14:28 becomes the preface of the Jerusalem Council, Acts 15, where the case of the inclusion of Gentile is determined. Therefore, the general ideological perspective of the narrator in the Jerusalem Council story is that the gospel is a universal reality that even the Gentiles are supposed to be included in the Christian community.

(iv) Space

According to Du Toit (2009:403), the concept of space refers to a number of things which include a place, where characters find themselves, like a temple in Jerusalem, and the way in which a place is presented. The way the narrator presents different spaces in his story influences and affects a variety of meanings that are attached to these spaces. In the Jerusalem Council (Acts 
15), the narrator concentrates on Antioch and Jerusalem which serve as his focal space. These places, then, define the atmosphere in which the narrative takes place. The conflict emanated in Antioch (15:1-2), is deliberated, determined, and officiated in Jerusalem (15:2b-29). It is also from Jerusalem where the envoys and letter are sent to Antioch, Syria and Cilicia to communicate the verdict of the council (15:30-35). Ultimately, the representatives who were sent to communicate the contents of the letter verbally to Antioch and other assemblies returned safely to Jerusalem $(15: 34)$.

The Jerusalem space contributed immensely towards the meaning which the narrator wanted to convey. Jerusalem became the centre of authority where dissention was resolved, yet, for the Jewish people "Jerusalem was regarded as the centre of the world" (Story, 2011:35; Bauckham, 1995:422). The narrator puts Barnabas and Paul's ministry in Antioch for the whole year (11:2526) and drew the attention of the readers to the issue that the disciples were first called Christians in Antioch (11:26). The narrator also proposes that it was in Antioch where prophets and teachers were filled by the Holy Spirit and were set apart to do the work which they were tasked by God $(13: 1-3)$. It is important that there is peace and tranquillity between the two cities. These two places serve as focal space, because it is from Jerusalem where there is a wider geographical movement of mission work to all corners of the world. These areas include, Judea (Acts 6:1-8:1) Samaria (Acts 8:1-40) and to the end of the world (Acts 9:1-28:31).

This section has analysed Acts 15:1-35 from a narrative perspective, considering aspects like surface structure, the narrator's psychological situation, narrator's spatial situation, the narrator's and the ideological perspective. It has been discovered that the role of the narrator is pivotal in as far as the narrative point of view is concerned. Meaning in the Jerusalem Council was determined by the narrator. He prepared the readers for a conflict-resolution in Acts 15 by the preceding chapters (10:1-14:28). The narrator's implied readers were psychologically ready to deal with Gentile inclusion in the Christian community.

\section{Characterisation}

Characters are sometimes called dramatis personae, in other words these are persons that are found in a story (Resseguie, 2005:121). Just like Peter in the story of the Jerusalem Council. The implied author creates a character who participates in the activities of the unfolding story. The biblical characters are not fictional as those of the secular world of literature.

\section{Peter}

The narrator of Acts depicts Peter as a pivotal personality in the early church community when he vigorously preached in open-air and at the Pentecost (Acts 2). Peter was also instrumental in undertaking the missionary expedition to Joppa, Lydda and Caesarea (9:32-10:2). His mission activities were vital in the decision to preach to the Gentiles. From the Synoptic Gospels, Peter was the leader of the twelve disciples. His leadership continued to the apostolic period. Vidmar (2005:39), a Catholic scholar, questioned the primacy of Peter as solely leading the Church. In other words, was Peter a Bishop of Rome or a leader of other apostles? Vidmar claims that "[b]oth Catholic and Protestant scholars agree that Peter had an authority that superseded that of the other apostles" (Vidmar, 2005:39). In a way, Peter played a supervisory role, for instance, he conducted the elections to replace Judas Iscariot, as well as his argument over the Gentile inclusion in the Christian community at the Council of Jerusalem (Acts 15) was crucial.

The view that Peter was the leader of other apostles is both optimistic and pessimistic. Optimistic because the letter of Clement to the Corinthians says that Peter's death locates him in Rome and is evidence that he was the leader there (Vidmar, 2005:39). Situating a person through letter 
writing is not enough evidence that he was a leader there, especially if the letter of Clement is not part of the Bible. According to Vidmar (2005:39), Ignatius of Antioch communicated with Romans saying, "[i] did not command you as Peter and Paul did." The implication of all the evidence cited above collectively points to the fact that Peter could probably be the leader in Rome. Negative evidence enunciated that there is no community or city which claims that Peter was its leader except Antioch (Vidmar, 2005:39).

The narrator crafted another dimension of Paul that stressed the view that they were together in Rome with Peter at the same time. The question that can be asked is: Who was the leader then? The evidence that we get from Gal 1:18 shows that Paul's leadership was determined by Peter's appreciation. An analysis of this argument is that Peter was really a leader of the apostles on the first lap of the book of Acts. It is also important to point out that Peter was sent by the Jerusalem Church to Antioch to supervise the work of Paul (Elmer, 2006:6). It is however not clear how James got to the centre of power in Jerusalem. At the Jerusalem Council James appeared to be in charge as evidenced by his declaration of the decree, "... my judgement is that we should not trouble those among the Gentiles who turn to God" (Acts 15:19). The view that Peter and Paul were co-bishops in Rome while Peter had a supervisory role is untenable given that in terms of authority Peter was more senior than Paul. The implied author of the Jerusalem Council story created Peter as one of the boldest apostles of them all, he underwent untold suffering when he was persecuted, put in prison, and being beaten (Acts 5:41). He chose to do what was disgraceful for the sake of the Lord.

Luke's pivot (Acts 15) shows three people or groups participated in the leadership of the church in the first half of Acts. The first part of Acts tells several stories based on Peter where 58 references were made Acts 1:13-12:18 (Story 2010:36). In Acts 15 there are two references which were made to Peter, yet the second lap of Acts Peter disappeared and is not even mentioned. It is not clear whether the narrator was not aware of Peter's activities or he deliberately did not include him. In Acts 15 both Peter and Paul took part in the deliberations of the meeting, but after the Jerusalem Council, Paul takes over and 113 references are made to him (Paul).

At the Jerusalem Council, Peter is one of the major characters in the story. He is introduced in the story by the narrator as a round character. Resseguie (2005:122) defines round character as one that is not predictable and his character "cannot be summed up in a single phrase". In other words, he is that character who can convincingly surprise his readers. This is true of the character of Peter, who surprised his readers by converting Cornelius a Gentle. He further surprised his readers by sharing the same table with Gentiles and when he saw fellow Jews, he withdrew from the table. In this case, the narrator was "telling" his readers that the character of Peter was bad according to Jewish traditions. It is the audience/reader who would make their judgement concerning the character of Peter. In this case, Peter is seen as a character that can surprise his audience and is therefore unpredictable.

Peter as a character in a story of the Jerusalem Council, is seen as someone who is courageous because he stood up in supporting the mission of Paul and Barnabas to the Gentiles. The narrator here "shows" the words and actions of a character to the readers the boldness of Peter, so that they could make their own inferences. The narrator's expressive remarks and explanations about a particular character can serve as "showing" the audience/reader the behaviour of a character in a story.

\section{Rhetoric}

The other literary device which is instrumental in analysing Acts 15 is rhetoric. According to Resseguie (2005:41), rhetoric is "the art of persuasion" which gives life into the story and 
stimulates how the reader thinks and feels about what the narrator is saying. Rhetorical skills are salient in every discourse, either oral or written. It is a way in which implied authors convince the implied readers of their values, ideologies, norms, and concerns (Aune, 2003:315). The rhetorical forms like repetition and hyperbolic expressions help the exegete to identify how a story is structured. Furthermore, irony helps the ideal reader to appreciate the implied author's theology or ideology in a given story. It is therefore, the purpose of this subtopic of rhetoric to analyse Acts 15 focusing on repetition, repetition of sequence of action, parallelism, rhetorical question, figures of speech among others.

\section{Repetition}

Repetition is a poetic device that repeats lexical items, expressions, thematic concerns, patterns, situations, and actions in order to reinforce or foreground the salience of that aspect. The deliberate use of repetition is meant to "add force and clarity to a statement or a motif" (Anderson, 1994:91). This technique is frequently used in the biblical stories in order to help detect norms, values, and beliefs that the narrator deems valid (Resseguie, 2005:42). This is what is found in Acts $15: 3 ; 7 ; 12 ; 17 ; 19 ; 23$, where the implied author argues for the legality of Gentile-inclusion. The seven times positive reference to the Gentiles show emphasis of the importance of including Gentiles in Christian community. Talbert (1997:136) observes that "the extension of the gospel to the Gentiles is followed by an episode of Jerusalem approval." Most importantly, the narrator conveys that the Gentile inclusion was actually divinely initiated. This is evidenced by what the narrator says in Acts 15:7, "God made a choice among you that the Gentiles might hear from my lips the message of the gospel and believe." Related to the positive references to Gentiles in Acts, the narrator further made sixteen references to Gentile ministry in the second part of Acts, that is, after the Jerusalem Council. One may argue that after the conflict was settled in Acts 15, the narrator concludes that Gentiles have access to God's salvation.

The narrator in Acts 15 utilised repetition as a stylistic device by repeating (un)circumcision five times in Acts, two of these refer to Abraham's covenant (Acts 7:8), four are in (Acts 15:1-16:5, and the other refer to (Acts 21:21). This stylistic device is meant to show the gravity of the sharp debate and dispute which were raging at the Council of Jerusalem. This tension emanated from the denial of the Gentiles who were not circumcised Gentiles to be admitted in the community of

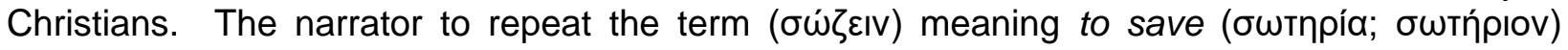
salvation seven times. Resseguie (2005:42) rightly says "[t]he smallest unit relies on the reiteration of key words and phrases to tie together diverse narratives, to elaborate a theme, or to establish an ideological point of view". The repetition of the verbal phrase to save could connect the themes which may seem unrelated at first sight. These repetitions of to save and salvation are supported by a variety of other salvific words which are central in Luke's work and which relate to a number of benefits of God's people (Story, 2010:40).

The verbal repetition may also enunciate the narrator's theology. The implied author uses citations from the prophets Amos 9:11, 12, and Isaiah 54:1-5 with four verbs in the first person singular. In this situation, God's voice is projected articulating what He will do, that is, "I will return"

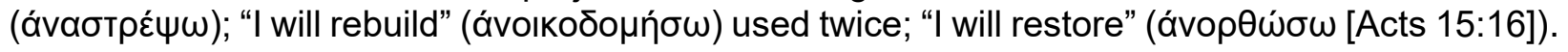
This extraordinary setting is at the backdrop of restoration and rebuilding of the ruins which came as a result of destruction. In a similar way, the repetition shows creates rhyming effect and places emphasis on God's initiative in embracing the Gentiles in the community of Christians.

There is the other stylistic device of repetition of the apostles and elders which the narrator used. There are 23 references to apostle(s) from chapter 1:2-14:14. Before the Jerusalem Council, the narrator argued that Barnabas and Paul nominated leaders in each respective congregation (Acts 14:23). The Jerusalem Council brought together the apostles and elders. The apostle(s) was 
repeated six times while for five times it was repeated as a paired expression (Story, 2011:36). The repetition of the apostles and elders emphasizes their roles of shepherding the Church of God. Barrett (2002:722) remarks that, "it is noteworthy that we hear nothing of the Twelve as the ruling body of the Church." It appears the apostles were not active in Acts with the exception of Peter, James and John who participated actively as apostles to the Jews before the Jerusalem Council. After the Jerusalem Council, the narrator only recounted the story of Paul alone as an apostle to the Gentiles.

\section{Repetition of sequence of action}

There is also a repetition of sequence of action in the book of Acts. According to Rhoads, Dewey, and Michie (1999:49), "this form of repetition relies on actions in numerical series (twos, threes, fours and so on) to create emphasis." In Acts for instance, the narrator uses a similar approach when a voice instructs Peter to eat three times. Peter saw a sheet coming from heaven with different kinds of animals. Peter was ordered to kill and eat. Peter said, "I have never eaten anything that is profane or unclean" (Acts 10:14). This voice created by the implied author was repeated more than twice and the sheet ascended to heaven. This three-time repetition highlights a spiritual understanding of the story, that is, "what God makes clean must not be treated as profane" (Witherup, 1993:46). It can be pointed out that the vision seen by Peter may also imply that Peter as an apostle should not be confined to the Jewish people but also accommodate the Gentiles. It is probable that soon after his vision, he (Peter) met Cornelius and he accepted the gospel as a Gentile. Peter drew from the Cornelius incident as an experience that was used to settle the dispute at the Jerusalem Council. In the same way, Peter's meeting with Cornelius is recorded three times with some differences (Acts 10:9-48; 11:5-18; 15:7-11). Therefore, a series of three sequences of action highlight underscore the fact that the action has reached a climax.

There is another form of sequential repetition of action in the way the decree was recorded Acts 15:20-21 and 15: 29 but with some variations. The apostolic decree was recorded twice; the first was announced by James to the effect that, "abstain from things contaminated by idols and from fornication and from what is strangled and from blood" (Acts15:20). Savelle (2004:49) argues that the later prohibitions of the decree which were relayed from the Council to congregations in Antioch, Syria and Cilicia had a different order (v.23). Despite the fact that there were variations in the order of the prohibitions of the apostolic decree, what is significant is that there is a sequential repetition of action. This action helped the narrator to emphasise the importance of the prohibitions to the Gentile believers.

\section{Parallelism}

Parallelism is another literary device which shows resemblance in the construction of two words, phrases, clauses, or syntactical makeup (Resseguie 2005:56). A similar situation is found in Acts 15:16 which says,
A "After this I will return
A and rebuild David's fallen tent.
B Its ruins I will rebuild,
B and I will restore it."

The example given above is borrowed by the narrator from Amos 9:11. In its context, it is against the backdrop of hope and restoration of the people of Israel. In the example given above, the first two clauses marked (A, A) are what Aune (2003:231) calls synonymous parallelism, while the 
second parallel clause marked $(\mathbf{B}, \mathbf{B})$ repeats the same idea but with different terminology. Fundamentally, there is a repetition of $I$ will... three times which is in the first person singular. However, scholars like Parsons (2005:214) argue that the literary device that is in Acts 15:16 is not parallelism but alliteration. He further proposed that this is so because of the repetition of the original sound like (I will return"); (two times "I will rebuild"); (“I will restore").

This research does not agree with Parsons because there is a clear repetition of the same ideas in the same verse which therefore suggests that it is parallelism. The significance of this parallelism is that God is taking the lead in restoring and rebuilding of the Kingdom of David and the rest of humanity (Bock, 2007:503). This resonates well with the situation on the Jerusalem Council where God Himself is taking the initiative to accept Gentiles into Christian community. There is a repetition of the verbs, 'return', '(repeated twice), and 'restore' emphasizing restoration. Marshall (2004:253) suggests that Amos' quotation helps to f "bring out more clearly the way in which the progress of the church is in accordance with the Old Testament prophecies". In other words, what is in this verse is the fulfilment of the scriptures which was proclaimed by prophets of the Old Testament that even the Gentiles should have a place in God's Kingdom.

\section{Rhetorical Question}

According to Resseguie (2005:60), a rhetorical question can be defined as "a statement in the form of a question that does not expect a reply but is stated to achieve greater persuasive power than a direct statement." It is difficult to give an answer to a rhetoric question because the answer would be just obvious. In the story of the Jerusalem Council, the narrator used this literary device when he said, "... why do you try to test God by putting on the necks of the disciples a yoke that neither we nor our fathers have been able to bear?" (Acts 15:10). This question does not require an answer. Peter was simply saying the Jews failed to obey the Mosaic Law and so they should not require this stipulation as a prerequisite for Gentiles. This demonstrates the usefulness of this stylistic device in a story. Peter used the mentioned rhetoric question to rebuke the hard-liners who insisted that the Gentiles should observe the law if they become members of the Christian community.

\section{Figures of speech}

In recounting his Jerusalem Council story, the narrator employs figures of speech. According to Aune (2003:231), figures of speech is "depart[ing] from customary or standard usage of language by the order and pattern of words and phrases." This is characteristic of the Jerusalem Council story where figures of speech are used such as, "the custom taught by Moses" (Acts 15:1). Bock (2007:494) suggests that this idiomatic phrase is in the dative case which may imply that "because of the custom of Moses" or "according to the custom of Moses" (Wallace, 1996:155; Witherington 1998:454; Haenchen 1987:446). Witherington (1998:454) proposed that it is probable that this phrase could denote the Jewish tradition. However, this could be unlikely because it appears it is a command which is probably coming from their descendent Abraham (Genesis 17:10-14).This was a prerequisite by the Jews that Gentiles should be are circumcised and obey Mosaic Law before receiving salvation. This figure of speech may refer to the "whole of the cultic law attributed to Moses" (Story, 2011:39). In other words, the Gentiles were expected to live according to the stipulations of the dictates of the Mosaic Law. In fact, they (Gentiles) were required to become Jews first before they were saved.

Related to above figure of speech which says"... putting on the necks of the disciples a yoke..." (Acts 15:10) the narrator used the rhetoric question to emphasise his point that those who force Gentiles to obey the law are putting God to test as it is written in Exodus 17:2 (Barrett, 1998:717; Fitzmyer, 1998:547). The narrator argues that the yoke was used with reference to the burden of 


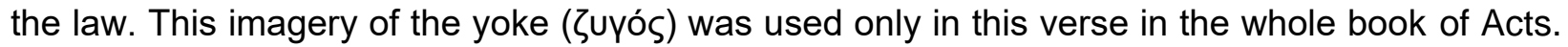
A yoke is a wooden or iron frame which is put on the neck of either a donkey or cattle when ploughing to curb unnecessary movement. In a similar way the yoke was the law which the Jews wanted the Gentile Christians to observe to restrict them from different things. However, scholars like Gaventa (2003:216); Le Cornu and Shulam (2003:825) and Jervell (1998:392) contend that the use of the yoke should be seen in a positive way. They think, Peter was suggesting that the law itself is not a problem, but the Gentiles' inability to keep it.

A critical analysis of this view shows that, the law in itself is holy (Romans 7), but its requirements are difficult to follow. Therefore, the narrator chose figures of speech in his story that makes an implied reader to pose and reflect on the unfolding of the story. This literary device has helped the implied author to develop his theme and let the story to unfold perpetuating conflict among the ethnic groups which were at the Council of Jerusalem.

\section{Chiasm}

Another literary device which has been utilised by the narrator in the Jerusalem Council story is a chiasm. Chiasm is a word which has been derived from a Greek letter X (chi) that signifies the crossover design of words, clause, phrases or concepts that are recurrent in reverse fashion (Resseguie, 2005:58; Aune, 2003:94; Heil, 2001:180). A simple form of a chiasm is A B B A- a construction which composes of a circle stressing main ideas in reverse fashion. This type of chiasm forms a structure with a series of four occurrences emphasizing the major concepts in reverse order. Parsons (2005:207) argues that the first verses (15:1-5) are organised in a chiastic arrangement as follows:

A People from Judea teach circumcision is necessary for the Gentiles' salvation (15:1)

B Paul and Barnabas (and others) are sent to Jerusalem to discuss the matter (15:2)

C On the way they relate the conversion of the Gentiles to believers in Phoenicia and Samaria $(15: 3)$

B' When they arrive in Jerusalem, they are welcomed by the church (15:4)

A' Some Pharisaic Christians say circumcision and keeping the law are necessary for Gentiles $(15: 5)$

There are some narrative scholars such as Dart (2003:52) who observes that chiasms have a number of narratives highlighting the main ideas in converse pattern. In this case this type of chiasm has five episodes. Parsons (2005:207) claims that the external structure of this chiasm proposes that the conflict in Acts 15 has interconnected but eventually different soteriological and social concerns. This chiasm highlights the conflict that was exacerbated by ethnic social identities in Luke's community.

\section{Implications to Zimbabwean Political Landscape}

The numerous different cultural identities in Zimbabwean society have often given in to sociopolitical and religious conflicts. This resulted in a highly polarised environment traceable to precolonial times. At the epicentre of ethnic polarity in the pre-colonial period was the quest search for arable land for crops, farming and grazing, which certainly caused in attacks and counterattacks as cultural groups wanted to outdo each other. It was precisely because of the quest for land and some resources that characterised the tension which existed between the Shona and the Ndebele (Beach, 1993:268). In view of the adversarial nature of their existence, stereotypes, 
prejudices and essentialized identity constructions of each ethnic group developed (Marevesa, 2020). This Otherisation politics in languaging finds expression in derogatory descriptions project binarity philosophy of the inferior and superior Other. Such divisive and dangerous dichotomies were capitalised by Whites political and economic control. The use of degrading, dehumanising and derogative terms in mudzviti /musvina discourse was constructed to justify divisive practices and domineering attitudes where the Other because a target of raids counter to the pluralist society. During war time, stereotypes were utilised to dehumanise the opponents. The increase in differences went beyond the territorial, linguistic and cultural boundaries.

According to Hall (1997:183), the negotiation between Ndebele people Shona people for a peaceful co-settlement in Mashonaland remains obscure and debatable. If they did, the Shona people most likely refused the request leading to the drawing of territorial demarcations between them. Marevesa (2020) posits that Ndebele or Shona identity in this scenario should be understood in terms of geographical space, language, values and norms.

This kind of negative relationship continued into colonial period in Zimbabwe, but transformed due to the coming of the white settlers who grabbed vital resources including the land and its resources. Beach (1974:637) observes that the White settler's occupied fertile land snatched away from the indigenous people who were forced into "Tribal Trust Lands" or "Reserves." The First and Second Chimurenga/Umvukela erupted as a consequence of exploitation, racial discrimination of the local black people (Dawson, 2011:144). Motivated by a common concern the Shona and the Ndebele people had to unite and wage a war against the white oppressor

Despite the adoption of a pluralist society ideology in post- colonial Zimbabwe, there is still political bickering in the country today due to ethnic and religious conflict motivated by many issues including Gukurahundi (1983-87) which took place in Matabeleland and Midlands provinces (CCJP/LRF 1997). What this shows is that in any natural misunderstanding between members of the two or more ethnic groups, there is the tendency to intone the ethnic litany that inevitably whips up divisive emotions (Marevesa, 2020).

The pluralistic society of the Council of Jerusalem in Acts 15:1-35 discussed above was a first century conference which was convened when there was a conflict between Gentile and Jewish and Christians on the criteria of accepting Gentile Christians into Jewish Christianity. Even though the Jerusalem Council is a first century conference, this study posits that there are biblical principles that can be relevant to the Zimbabwean pluralistic and ethnic diversity ideology. In addition the Zimbabwean pluralistic environment is evident in political situation. In 2008 Harmonised elections which gave birth to the Global Political Agreement hereafter (GPA), only 5 political parties. The political diversity was also witnessed in the 2018 Harmonised Elections which showed an increase in participation of 133 political parties and 23 presidential candidates (Zimbabwe Human Rights Commission 2018 Harmonised Election Report). These different political parties represented various ethnic, social and religious groups in Zimbabwe. The reconciliation in Zimbabwe should be understood in terms of the signing of the GPA among the main political parties. The GPA was a political agreement which was signed among three political parties.

\section{The process of conflict-resolution in the pluralistic Zimbabwe}

It has been established that the diversity in ethnic identities in Zimbabwe can be traced to pre, colonial and in the independent society. In all those epochs, there was a recurrent conflict between the various ethnic and political groups. This tension was shortly resolved during the GPA in September 2009 (Raftopoulos, 2007). The former South African president Thabo Mbeki facilitated the conflict resolution in Zimbabwe among the major political parties, Robert Mugabe's 
Zimbabwe African National Union Patriotic Front (ZANU PF, Morgan Tsvangirai's Movement for Democratic Change -Tsvangirai (MDC-T) and Mutambara's Movement for Democratic Change M (MDC-M).The mediation which he did to bring the warring parties to the negotiating table was a big stride in resolving the political impasse that had rocked Zimbabwe. The process of conflict resolution was reached after a series of negotiations among the major political parties. As a way to transform the conflict in Zimbabwe, the GPA proposed that there should be an Organ on National Healing, Reconciliation and Integration (ONHRI). This idea /arrangement is/was similar to what was done during the time of the Unity Accord in 1987 which saw ZANU PF led by Robert Mugabe and PF ZAPU led by Joshua Nkomo making a show of unity (Muzondidya, 2009:179). The unity accord tried to resolve ethnic and political conflict. This took place after the Gukurahundi which happened in the Midlands and Matabeleland provinces from 983 to 1987. As a conflictresolution measure, the GPA infused the article VII which articulated the tenets of unity, national healing, and equality to be realized in the new Zimbabwe. Section 7.1 provided direction to the new government where it was to:

a) "...ensure equal treatment of all regardless of gender, race, ethnicity and place of origin, and to work towards equal access to development for all;

b) ...give consideration to the setting of a mechanism to properly advise on what measures might be necessary and practicable to achieve national healing, cohesion and unity in respect of victims of pre- and post-independence political conflict;

c) ....strive to create an environment of tolerance and respect among Zimbabweans and that all citizens are treated with dignity and decency irrespective of age, gender, race and ethnicity, place of origin or political affiliation"(The Global Political Agreement in Zimbabwe, 2008:7)

The ONHRI got its mandate from section 7(c), and the other sections in this article deal with the major role of the organ during the Government of National Unity (GNU). According to Chipaike (2013:17), the ONHRI did not perform well to bring forth the much needed reconciliation and healing in Zimbabwe. The members of the organ who were Sekai Holland of MDC-T, John Nkomo of ZANU PF, and Moses Mzila Ndlovu of MDC-M seemed not to be proactive in the communities they were supposed to be working in terms of advocating for reconciliation and healing. According to the Newsday (27 July 2012), the members of the organ simply issued statements in the media advising people to desist from political violence.

One could argue that if the organ wanted to be proactive, they could have engaged the communities against violence. They could have made use of traditional chiefs and churches to penetrate all spheres of the communities as well. As the organ of the Inclusive Government, the ONHRI had the obligation to inform the public on the precautions that had to be taken to bring healing, reconciliation and cohesion. The organ could have made some recommendations to the government on the programmes that were supposed to be done to create conditions that were necessary for reconciliation and peace. Chipaike (2013:23) is right in saying that the major reasons of its failure range from its elitist outlook to lack of conflict transformation expertise. The members of the organ were just hand-picked to represent their parties as politicians not as experts of conflict-resolution. So, it was not easy for them to drive a programme of conflict-resolution that brings national healing in Zimbabwe.

The Government of National Unity could have done much better if it had included civic organisations such as the Zimbabwe Community Conflict Resolution Agenda, Women's Coalition of Zimbabwe, Zimbabwe Human Rights, NGO Forums, academics and churches (Chipaike 2013:25). These could have given technical advice to ONHRI and the Joint Monitoring and Implementation Committee (JOMIC) on how to resolve conflict and bring national healing in Zimbabwe. In other words the organ ignored the efficacy of narratology, which calls upon the 
aggrieved to consciously narrate the story while the rest listen attentively motivated by the need to genuinely resolve the problem. The Councillors of the Jerusalem Council were good at this, and serve as a good example for currently unresolved conflicts in Zimbabwe.

\section{Conclusion}

This paper concurs with De Villiers (2013:145) that the accomplishment of resolving a conflict is an outcome of critical consideration, dialogue and compromise. In this paper, it was observed that the ethnic conflict-resolution at the Council of Jerusalem was resolved by all the delegates who were present. The ethnic conflict was resolved through debates, mediation and compromise. However, the conflict in the pluralistic society of Zimbabwe is difficult to resolve because of the high polarisation which has existed between the Ndebele and the Shona for decades. It has proved difficult to bring the two ethnic groups to the negotiating table because of finger-pointing and mudslinging. In the current political situation in Zimbabwe, conflict resolution between ethnic and political tension was briefly solved by the signing of the GPA. However, this was short-lived because the GPA expired. There is still room for further research and investigation into the ethnic and political conflict resolution in Zimbabwe.

\section{References}

Akerlund, A. (2005). Transforming Conflicts and Building Peace: Experience and Ideas of Swedish Civil Society Organisation. Stockholm: Sidastudies.

Anderson, J.C. (1994). 'Matthew's Narrative Web: Over, and Over, and Over again,' JSNTsup 91. Sheffield: Sheffield Academic Press, pp. 91-102

Aune, D. E. (2003). The Westminster Dictionary of the New Testament and Early Christian Literature and Rhetoric. Louisville: Westminster John Knox.

Barrett, C.K. (2002). Luke (ICC) Vol 11. London: T \&T Clark.

Bauckham, R. (ed.) (2005). James, Peter, and the Gentiles' in the Missions of James, Peter, and Paul: tensions in Early Christianity. Leiden: Brill, pp. 135-139

Bauckham, R. (1995). The Book of Acts in its Palestinian Setting 4. Eerdmans: Grand Rapids.

Bauer, W. et al (1979). A Greek-English Lexicon of the New Testament and Other Early Christian Literature. Chicago: University of Chicago Press.

Beach, D. (1974). Ndebele Raiders and Shona Power, The Journal of African History, 15(4), 633651.

Beswick, D. \& Jackson, P. (2011). Conflict, Security and Development: An introduction. London: Routledge.

Bock, D. (2007). Acts: Baker Exegetical Commentary on the New Testament. Michigan: Baker Publishing Group.

Brant, A.J. (2004). Dialogue and Drama: Elements of Greek Tragedy in the Fourth Gospel. Mass: Hendrickson.

Brown, R. E. (2004). "Acts of the Apostles" in The New Jerome Biblical Commentary. New York: Bloomsburg Publishers. 
Bruce, F.F. (1990). The Acts of the Apostles: The Greek Text with Introduction and Commentary. (Third revised and enlarged edn), Leicester: Apollos.

CCJP and LRF. (1997). Breaking the Silence: Building the True Peace (A Report on the Disturbances in Matabeleland and the Midlands 1980-1988), Gweru: Mambo Press.

Counet, P.C. (2001). John, a Postmodern Gospel: Introduction to Deconstructive Exegesis Applied to the Fourth Gospel. Leiden: Brill.

Culpepper, R.A. (1983). Anatomy of the Fourth Gospel: A Study in Literary Design. Philadelphia: Fortress Press.

Campbell, W.S. (2010). "The Narrator as "He," "Me," and "We": Grammatical Person in Ancient Histories and in the Acts of the Apostles", Journal of Biblical Literature, 129(2), 385-407.

Dart, J. (2003). Decoding Mark. Harrisburg: Trinity Press International.

Dawson, S. (2011). "The First Chimurenga: 1896-1897 Uprising in Matabeleland and Mashonaland and Continued Conflicts in Academia", Constellations 2 (2), pp.144-153.

Dibelius, M. (2000). The book of Acts: Form, Style, and Theology. Minneapolis: Fortress Press.

Dunn, J.G.D. (2006). Unity and Diversity in the New Testament: An Enquiry into the Character of Earlier Christianity. Louisville: Westminster John Knox.

Dunn, J. G. D. (1996). The Acts of the Apostles. Valley Forge: PA Trinity.

Ehrman, B.D. (2009). A Brief Introduction to the New Testament. Oxford: Oxford University Press.

Elmer, I.J. (2006). Between Jerusalem and Antioch: The Advent of the Gentile Mission, Australian eJournal of Theology 6, 1-6.

Gaventa, B.R. (2003). The Acts of the Apostles. Nashville: Abingdon Press.

Glass, M. (2004). http://www.cirp.org/page/cultural/glass. Date accessed 15/09/2015, 2:15.

Gunduza, M.L. \& Namusi, C.W. (2004). Negotiation in Conflict Management Module LIR 303. Harare: Zimbabwe Open University.

Gundry, R. H. (2003). .A survey of the New Testament (4 ${ }^{\text {th }}$ edition). Michigan: Grand Rapids.

Harmon, W. \& Holman, C.H. (1999). A handbook of Literature (8 ${ }^{\text {th }}$ edition). Upper Saddle River: N.J. Prentice Hall.

Gusha, I. S. (2017). Ndebele and Shona Ethnic Cohesion: A Dialogue with Paul's Ethics of Reconciliation. PhD Thesis. Pretoria: University of Pretoria.

Hall, S. (1997). Representation: Cultural Representation and Signifying Practices. London: Sage Publication.

Heil, J. P. (2001). The Chiastic Structure and Meaning of Paul's Letter to Philemon, Biblica 82, 178-206. 
Instone-Brewer, D. (2009). Infanticide and the Apostolic Decree of Acts 15, Journal of the Evangelical Theological Society, 52 (2), 301-321.

Jervell, J. (1998). The Theology of Acts. Eerdmans: Grand Rapids.

Keener, C.S. (2012).Acts: An Exegetical Commentary Vol. I: Introduction and 1:1- 2:47. Michigan: Baker Publishing Group.

Le Cornu, H. \& Shulam, J. (2003). A Commentary on the Jewish Roots of Acts. Jerusalem: Academia.

Malcolm, L. (2002). Conversion, Conversation and Acts 15, Crux, 22(3).

Marguerat, D. \& Bourquin, Y. (1999). How to read the Bible Stories. London: SCM Press.

Marshall, H.I. (2004). The Acts of the Apostles, Tyndale New Testament Commentaries. Eerdmans: Grand Rapids.

Marevesa T. (2019). "Social Identity Complexity and conflict-resolution in Luke and Zimbabwe" PhD thesis, Pretoria, University of Pretoria.

Matsikidze, R. (2013). Alternative Dispute Resolution in Zimbabwe: A practical approach to Arbitration, Mediation, and Negotiations. Harare: Molhurst Printers and Publishers.

Metzger, B.M. (1971).A Textual Commentary on the Greek New Testament, A Companion Volume to the United Bible Societies. Greek New Testament, ( $3^{\text {rd }}$ edition). London: United Bible Societies.

Metzger, B.M. (1994).A Textual Commentary on the Greek New Testament, A Companion Volume to the United Bible Societies. Greek New Testament. (4 ${ }^{\text {th }}$ Revised Edition), Stuttgart: Deutsche Bibelgesellschaft.

Musingafi, M.C.C. et al. (2011). Conflict Resolution Module BSDS 306. Harare: Zimbabwe Open University.

Park, D. H. (2010). Drawing Ethical Principles from the Process of the Jerusalem Council: A New Approach to Acts 15:4-29, Tyndale Bulletin, 61(2), 272 -291

Parsons, M.C. (2005). Acts: ПAIAIA - paidea Commentaries on the New Testament. Michigan: Brazos Press.

Proctor, J. (1996). "Proselytes and Pressure Cookers: The Meaning and Application of Acts 15:20", International Review Mission 85, 469-483.

Prutt, D. and Cornevale, P.J. (1993). Negotiation in Social Conflict. Buckingham: Open University Press.

Resseguie, J. L. (2005). Narrative Criticism of the New Testament: An Introduction, Michigan, Backer Academic.

Resseguie, J. L. (2001). "The Strange Gospel: Narrative Design and Point of View in John", Biblical Interpretation Series 56. Leiden: Brill. 
Resseguie, J. L. (2000). "New Testament as Literature," in D.N. Freedman (ed.) Eerdmans Dictionary of the Bible. Eerdmans: Grand Rapids.

Rhoads, D., Dewey, J. \& Michie, D. (1999). Mark as Story: An Introduction to the Narrative of a Gospel (2ndedition). Minneapolis, Fortress Press.

Savelle, H.C. (2004). "A Re-examination of the Prohibitions in Acts 15", Bibliotheca Sacra 161, 449-468.

Schwartz, D. R. (1996). God, Gentiles, and Jewish Law: On Acts 15 and Josephus' Adiabene Narrative. Tubingen: JCB Mohr.

Spoelstra, M. \& Pienaar, W. (1996). Negotiation: Theories, Strategies, and Skills (2 ${ }^{\text {nd }}$ edition). Kenwyn: Juta and Co. Ltd.

Swanson R.J. (1998). New Testament Greek Manuscripts: Variant Readings Arranged in Horizontal Lines against Codex Vaticanus, the Acts of the Apostles. Sheffield: Sheffield Academic Press.

Tannehill, R.C. (1990). The Narrative Unity of Luke-Acts: A Literary interpretation. Volume 2: The Acts of the Apostles. Minneapolis: Fortress Press.

Talbert, C. (1997). Reading Acts, New York: Crossroad.

The UN Conflict Resolution Manual. (2001). Skills Development for Conflict Transformation. New York: United Nations.

Tyson, J.B. (2008). Themes at the Crossroads: Acts 15 in its Lukan Setting, Forum (New Series) 4(1) (spring), 56-74

Twelftree, G.H. (2009). People of the Spirit: Exploring Luke's View of the Church. Michigan: Grand Rapids.

Wallace, B.D. (1996). Acts: Introduction, Argument and Outline. New York: Dallas Theological Seminary Publication.

Witherup, R.D. (1993). "Cornelius Over and Over and Over Again: 'Functional Redundancy' in the Acts of the Apostles," Journal for the Study of the New Testament, 49, 45-66.

Zimbabwe Human Rights Commission Harmonised Election Report 2018, Zimbabwe Human Rights Commission Kubatana. Net 